\title{
NEGOTIATING CONTINUITY AND CHANGE IN INDONESIAN ISLAMIC HIGHER EDUCATION
}

\author{
Ronald Lukens-Bull \\ The author is Associate Professor of Anthropology at the University of North Florida. \\ He conducted this research while he was Fulbright Senior Scholar at Institut Agama Islam Negeri, \\ Sumatra Utara in Medan, Indonesia. \\ Ronald.lukens-bull@fulbrightmail.org.
}

\begin{abstract}
Abstrak
Pendidikan Tinggi Agama Islam Negeri adalah komponen penting Islam di Indonesia dan menjadi sarana di mana pemerintah dan masyarakat Muslim Indonesia masing-masing berusaha untuk mendefinisikan Islam Indonesia. Lembaga ini telah terlibat dalam perdebatan tentang karakter Islam Indonesia sejak awal berdirinya. Baru-baru ini, IAIN dan UIN mengalami pergeseran dari mandatnya semula yaitu mencetak tenaga pendidikan Islam dan pejabat pemerintah Islam Indonesia. Hal ini telah menimbulkan kekhawatiran tentang masa depan lembaga itu sendiri. Selanjutnya, sebagian kalangan mulai mengkhawatirkan tentang apa yang disebut perspektif "liberal" atau "progresif" yang banyak ditemukan di beberapa kampus. Akhirnya, mengedepankan tradisi pesantren di kampus-kampus IAIN/UIN selama ini menjadi salah satu cara untukmenangani isu tersebut.
\end{abstract}

Kata Kunci : Kelangsungan, Perubahan, Pendidikan Tinggi Islam

\section{Abstract}

State Islamic Higher Education is a critical component of Islam in Indonesia and the ways in which the government of Indonesia and the Muslim community each seek to define Indonesian Islam. These institutions have been embroiled in debates about the nature of Islam since their beginning. Recently, IAIN and UIN have moved beyond their original mandate of training Islamic teachers and government officials. This has raised concerns about their future. Further, some have been concerned about so called "liberal" or "progressive" perspectives found on the campuses. Finally, an emphasis of the pesantren tradition on IAIN/UIN campuses has been one way in which these concerns have been addressed.

Keyword: Continuity, Change, Indonesian Islamic Higher Education

\section{INTRODUCTION}

PTAIN are critical to understanding the Indonesian Islamic community both for the ways in which they define orthodoxy and act as culture brokers to the wider Islamic community, as well for their cultural brokerage with Western philosophy and scholarship. This system plays a central role in the critical reexamination of Islam as well as acts as a bridge between various strains of Islam because students come from diverse Muslim backgrounds. ${ }^{1}$ Not only are the institutions and their faculty and staff important participants in the discourse about the future, they are

${ }^{1}$ Kraince. 2008. "Islamic higher education and social cohesion in Indonesia." Prospects 37(3): h. 349 
subjects of it as well. There is no shortage of discussion from on and off campus about what Indonesian Islamic higher education should be and how best to achieve those goals. These discussions are a significant part of on-going debates about the future of Indonesia.

This paper is based on five months research on National Islamic Higher Education in Indonesia in 2008-2009. In addition to teaching in the doctoral program at IAIN-SU, the author presented guest lectures at other Islamic colleges and universities. The author also conducted participant observation and interviews on five IAIN/UIN campuses. This paper sketches several key pointes that are explored in further detail in my forthcoming book, Islamic Higher Education in Indonesia: Continuity and Conflict (Palgrave).

The PTAIN system started in earnest in the 1970s by combining two preexisiting institutions for the training of Islamic teachers and government functionaries. In 1945, a private institution called Sekolah Islam Tinggi (Advanced School of Islam) was founded in Jakarta. Later this institution moved to Yogyakarta and became the Universitas Islam Indonesia (UII). The Faculty of Religion at the UII became a government institution in 1950, called the Perguruan Tinggi Agama Islam Negeri (PTAIN; National Islamic College). In 1957, the government also founded the Akademi Dinas Ilmu Agama (Government Worker' Academy of Religious Science) in Jakarta. In 1960, these two institutions combined to become IAIN with a campus in Yogyakarta which offered the faculties of Ussuluddin (Islamic theology and comparative religion) and syariah (Islamic law) and a campus in Jakarta which offered the faculties of education and history. Historically, the largest faculties in IAIN, across all campuses, were Syariah (Islamic law) and Tarbiyah (education). These two faculties provide the judges, officials, and teachers for Indonesia's religious bureaucracy and religious educational system. ${ }^{2}$

${ }^{2}$ Karel Steenbrink. 1974. Pesantren, Madrasah, Sekolah: Pendidikan Islam dalam Kurun Modern. Jakarta: LP3ES, h.159
Some have argued that the IAIN (in Jakarta and Yogya) were "gifts" to the pesantren community to appease them after the "gift" of UGM (Universitas Gajah Madah) was given to the nationalists. This interpretation is subject to debate, but especially in Java, there is a strong sense of historical continuity between pesantren and IAIN. On Java, there still seems to be a strong connection between pesantren and the IAIN in that many students and instructors have pesantren backgrounds. However, on Sumatra, while the connection still exists, a much smaller percentage of the students and instructors have previously studied in pesantren.

\section{EVOLUTION OF SOME IAIN INTO UIN}

Starting in the late 1990s and early 2000s, six IAIN transformed from Institutes to Universities by adding at least two nonreligious fakultas. The motivation for these changes included concerns about employability of students and wanting to make sure that the Muslim community was not economically marginalized. Opinions about these changes are mixed both on and off campus. On campuses that have made the change, there is some concern about what will happen to the original religiously oriented fakultas; that the new, "secular" fakultas will provide too much competition and will eventually drive their fakultas out of existence. On campuses that have not made the change, there has been a call for a wider mandate. That is, they are adding programs like Psychology, Nursing, Management, and Public Health under the existing fakultas. IAIN North Sumatra received the specific recommendation to create a Public Health program in their faculty of Ushuluddin (theology and comparative religion) ${ }^{3}$ despite not having the staff to do so. Off-campus, some are concerned about the quality of the non-

${ }^{3}$ This is not as strange a suggestion as might first be assumed. Comparative religion often draws on social science as does Public Health. It is the social science components of both that suggest the appropriateness of that placement. 
religious programs and conclude that at least for the time being these are not the best places to pursue non-religious topics. The addition of non-religious fakultas has introduced some debate about the supervision of PTAIN, with the Ministry of Education claiming oversight over the new programs.

Some critics go so far as to accuse specific PTAIN faculty members of apostasy, although these accusations never carry much weight. Debate and concern about the future of State Islamic Higher Education is not new. In the 1990s, it was not apostasy or even liberalism that was the problem. Rather, the worry was that IAIN might not be as capable of training future ulama as traditional (salaf) pesantren. IAIN graduates were not able to read the traditional religious commentaries (kitab kuning).

In 2008, it seemed that the UIN conversion process was over. There had been a ministerial decree from then Minister of Religious Affairs Maftuh Basyuni, that there were to be no more UIN, but it allowed for the possibility of a wider mandate for IAIN, a concept adopted by both the Ministries of Religious Affairs and Education as a way to bridge between being religion-only institutes and full universities. ${ }^{4}$ But as often seems the case in Indonesia, with a new change in Minister, came a change in policy and some IAIN are now in the process of applying to become UIN. The debates (whether on or off campus) are far from over. Like many debates about education, these debates about PTAIN concern differences over the purpose of the institution and not only its future but also the future of society, in general.

For some, employability of graduates must be an essential part of the vision for PTAIN. Komaruddin Hidayat (Rector at UIN Jakarta) said his vision for UIN Jakarta is for it to become a center of scholarship and civil society. For many at IAIN, the concern is not only about development but also making sure that the Muslim community, especially those from pesantren, share in future economic growth and not become further marginalized.

\footnotetext{
${ }^{4}($ Azra 2011: 44)
}

He was also concerned about how to make it so that graduates care about society and to have a strong character as well as strong academic records in keeping with the UIN Jakarta motto of "knowledge, piety, and integrity." Hidayat acknowledges that not all faculty are of the highest caliber and there are not enough PhDs in each field, but maintains that as a whole, UIN Jakarta is an excellent university. He argues that to improve the scholarship on campus and to become a world class research university, they need professors who are the best in their field. He wants UIN Jakarta to create cadres of graduates who can build the future for Indonesian by imbuing them with optimism and enthusiasm. ${ }^{5}$

Visions for the future of PTAIN are not limited to those on campus. Traditional leaders like kyai do not want PTAIN to be ideological neutral. The greatest concern of kyai and even society at large is that students are pious; many in society at large are less concerned about academic accomplishment. Many faculty members and administrators have identified an opportunity -- to structure an environment so that the desired piety is delivered without committing to what many consider to be an outdated educational agenda. Yatsir Nasution, the Rector of IAIN North Sumatra when I taught on his campus argued that the traditional focus of PTAIN was on creating graduates who excelled in the Islamic sciences. In the past, what was called the Islamic Sciences or the Islamic Studies was limited to classical topics like figh, syari'ah, tafsir, and Sufism. Recently, they have sought to expand the meaning of Islamic Studies, so all the sciences that can be influenced by the Islamic-based philosophy of science are included. He wished to avoid controversies regarding a dichotomy between Islamic and non-Islamic studies by creating a wide range of academic fields influenced by Islam. ${ }^{6}$

\footnotetext{
${ }^{5}$ (interview, February 2009)

6 (interview, November 8, 2008).
} 


\section{SECULARISM, PLURALISM, AND LIBERALISM}

A significant part of Indonesian Muslim discourse over most of the last decade surrounds conservative concerns around secularism, pluralism and liberalism, known collectively by the pun sipilis (syphilis), a concatenation of these three terms meant to suggest that they are a corrupting social disease. In a July 2005 edict (fatwa) from the Indonesian Ulama Council, or Majelis Ulama Indonesia (MUI) declared these three ideas to be deviant and should be repudiated by all good Muslims (MUI 2005). The edicts of MUI do not carry any official weight and do not always carry any unofficial weight, either. The Islamist group Dewan Dakwah Islam Indonesia (DDII) endorsed this MUI edict and instructed DDII affiliated preachers to support it. Cholil Ridwan, who is both a DDII leader and a MUI executive said,

People who are against the edicts are munafikin (hypocrites) and are more dangerous than kafir, since they attack from inside Islam. ${ }^{7}$ Although the edict addresses a trifecta of progressive ideas, the central concern in Indonesian discourse is secularism with liberalism and pluralism being symptomatic of the larger issue.

The issues of pluralism, tolerance and religious freedom are central debates about the future of Islam in Indonesia and they found their way into the PTAIN campuses. In 1999, IAIN Syarif Hidyatullah in Jakarta took on the role of developing a civic education course. ${ }^{8}$ The design of the curriculum, was based in part on a survey that was conducted across various IAIN campuses. During the Suharto Regime there was mandated training in the national ideology of Pancasila (Five Principles) at all levels of education. The goal of this education was focused on social integration

\footnotetext{
$7 \quad$ (Jakarta Post 2005)

8 Elisabeth Jackson, and Bahrissalim. 2007. "Crafting a New Democracy: Civic education in Indonesian Islamic universities." Asia Pacifc Journal of Education 27(1): h. $41-54$
}

and national unity. ${ }^{9}$ It was a de facto peace and pluralism training program. When IAIN Jakarta recast this curriculum in the post-Suharto era, they first retrained the former instructors of the Pancasila curriculum. some of those trained not only taught the new curriculum on their own campuses but also trained other faculty at other public and private Islamic institutes. This new civic education program has not been mandated, so different campuses have adopted different aspects of the curriculum. For the instructor of this course at IAIN North Sumatra, collaborative learning is at the heart of civic education; not just a way to transmit the information but as a way to manifest the core lessons of cooperation, collaboration, and conflict resolution. In general, the civic education curriculum is considerably broader than the Pancasila education which it replaced and includes an examination of theories about democracy, participation, and development.

The term liberal Islam does not originate in Islamic discourse but in Western scholarship about it. ${ }^{10}$ Bustaman-Ahmad traces liberal Islam's growth in Southeast Asia to the influence of Harun Nasution and Nurcholish Madjid. He identifies several factors that might lead someone to be associated with "liberal" Islam. The first is having a pesantren education; their familiarity with the text and methods of this tradition allowed them to develop into critical scholars. Another educational commonality is time spent at Al-Azhar and the Islamic education model at IAIN, which allows students to examine a wide range of Islamic scholarship. Further, there are important "Western influences" including liberal "Middle Eastern" Muslims in the West (Fazlur Rahman, Muhammad Arkoun, and Fatima Mernissi) and the influence of western Indonesianists who have had a role in their education. Other factors include being involved with international NGOs and the general influence of Abdurrahman Wahid on Indonesian discourse. ${ }^{11}$

\footnotetext{
9 Kraince. 2008. "Islamic higher education and social cohesion in Indonesia.” Prospects 37(3) h. 347

10 (Bustaman-Ahmad 2011: 100)

11 (Bustaman-Ahmad 2011: 105-106).
} 
The apostasy accusations aimed at both individual professors and at UIN themselves are not taken seriously on campus, but the rhetoric is not unique. Hanging in front of the Islam Defender's Front (FPI) Headquarters is a sign that labels all forms of progressive Islam as apostasy. The main slogan says, "Eliminate Liberal(s), Dismantle Ahmadiyah," thereby linking liberal, progressive Muslims with minority religious group that self-identifies as Muslim but recognizes a prophet after

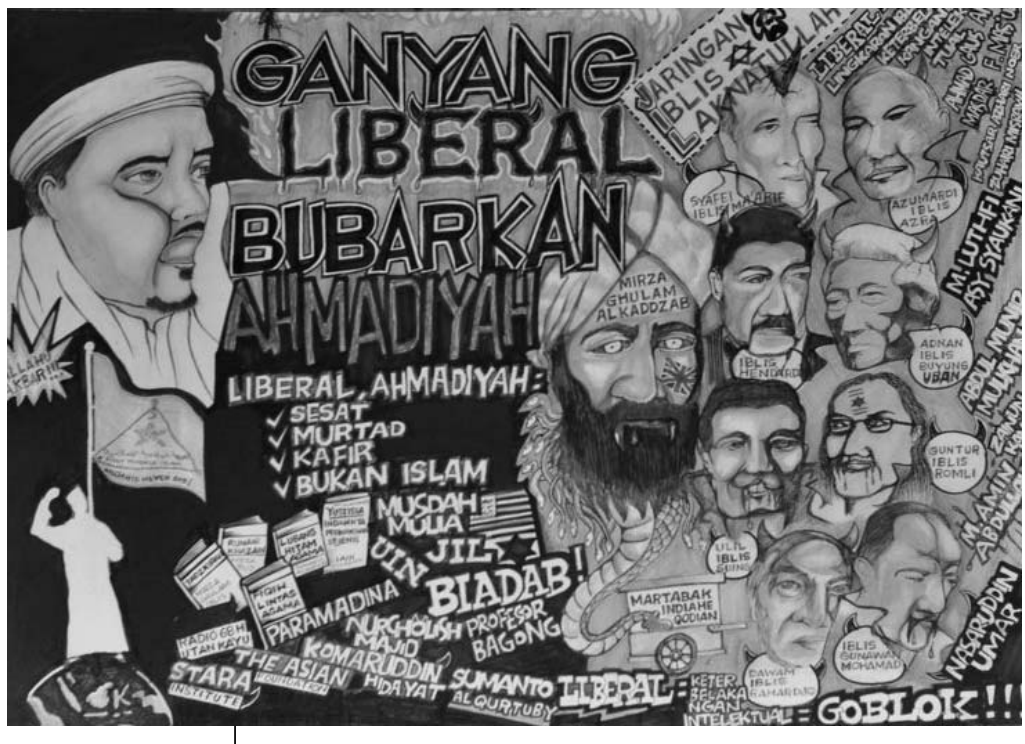
Muhammad. Ahmadiyah has Figure 1: Sign in front of FPI HQ in Jakarta (photo: faced persecution and violence in Indonesia. By linking progressive Islam including all of the State Islamic Universities (UIN) with Ahmadiyah, this sign is a none too subtle call for violence against progressives. The checklist asserts that liberal, progressive Muslims and Ahmadiyah are lost (sesat), apostates (murtad), unbelievers (kafir), and not Islam (bukan Islam). The sign accuses all UIN, the Liberal Islamic Network (which it calls the God Damned Devil Network), and Paramadina (a progressive Muslim organization and university) of being non-Muslim. It also names specific person including the rector of UIN Jakarta. These kinds of opinions may not have widespread support, but it is a mistake to be dismissive of them. Groups like FPI are playing an important role in Indonesia, many would say a disproportionately important role, in shaping public opinion.

While off-campus groups and individuals will include democracy in their definition of liberalism and secularism, those on campus who otherwise are part of the "conservative turn" would not. ${ }^{12}$ On-campus conservatives want to limit liberalism, in the sense of something Muslims should reject, to liberal hermeneutics of the sacred texts. They support freedom of thought and expression within certain limits, namely that a person

$12 \quad$ (van Bruinessen 2013)

Mark Woodward).

should position themselves first and foremost as a Muslim. One conservative at UIN Yogya argued that faculty members who position themselves, first as a social scientist and not as Muslim should not remain as faculty members in the PTAIN system. This argument harkens back to the model of PTAIN as a big pesantren and PTAIN professors as a potential source of religious leadership. This is one model for how PTAIN should interact with society but it is by no means the most commonly accepted model.

Professors accused of being liberal explained to me why they thought the label was applied to them, although none of them used it for themselves. One said it was because he is not content with the status quo with Muslim thinking and is critical of a MUI fatwa declaring smoking as haram (forbidden). His point is not to defend smoking or the tobacco industry but to question why the MUI isn't tackling more important issues like wealth inequity or corruption. Another says he is considered too liberal because his academic work examines the literary aspects of the Quran. For some, examining the Quran as literature denigrates it. Another told me that he is considered too liberal because he advocates for women's rights and human rights and argues that they 
are consistent with the spirit, if not the letter, of the Quran.

\section{CREATING PESANTREN ENVIRONMENTS ON CAMPUS}

The twin concerns that PTAIN are losing their religious focus and that they are perhaps too liberal has lead to the reemphases of the Islamic environment created on such campuses by drawing on aspects of the pesantren tradition.. At UIN Malang there is an on-campus pesantren in which all freshmen are required to live. To an outsider, these might appear to mere be dormitories, however the students are organized in ways similar to pesantren and special attention is paid to their spiritual, moral, and character development, exactly like a traditional pesantren.

Once when visiting UIN Malang, I was allowed to stay in a guest house inside the compound of the on-campus pesantren. As day gave way to evening, milling college students in shirts and trousers (sometimes even jeans and t-shirts) give way to santri in sarongs, long sleeve shirts, and peci. But, it's the exact same young men. As is typical of pesantren for university students, the pesantren education takes place in the early morning before classes and in the evening after class. ${ }^{13}$ It is absolutely required for all first year students, even those in a general fakultas, to stay in the pesantren. Second year students may elect to continue to reside in the pesantren; upwards of 200 students do so each year. Although the facilities have capacity for 1600 men and 2000 women only a total of 1600 students, men and women, currently live within the grounds. The stated goal is to create a pesantren in a university setting, to blend the two institutions to create intellectuals who are ulama and ulama who are intellectuals.

A special feature of the pesantren at UIN Malang is the focus on learning Arabic. In addition to the normal schedule of introductory courses, and pesantren lessons, first year

\footnotetext{
${ }^{13}$ (Lukens-Bull 2001).
}

students spend 5-6 hours daily studying Arabic to address some of the concerns about language ability that were debated in the mid90s. All graduates have more than rudimentary skill in Arabic although since they come in at different levels of competency, they leave with different levels of competency.

UIN Malang's on-campus pesantren is particularly interesting in the context of educational crisis faced by the pesantren community in the mid-1990s. The problem was that pesantren, like Tebu Ireng, who had added the government curricula were no longer able to produce graduates with the basic skills to be religious leaders. It was widely accepted that the training of leaders was going to be through the IAIN system but there was significant dissatisfaction with the system. IAIN graduates in the $1990 \mathrm{~s}$ did not possess the basic competency in Arabic to read and understand the classical Islamic text (kitab kuning) which was of high importance to the pesantren community. Jabar Adlan, then Rector of IAIN Sunan Ampel in Surabaya tried to establish extracurricular session on kitab kuning (classical texts), but due to lack of interest he abandoned this effort. Mark Woodward reports that the Muhummadiyah University system faced and is facing similar difficulties in created ulama and other religious leaders. ${ }^{14}$

There are certain symbols present that to the trained eye signal the connection with pesantren and with NU. Once such symbol is the large drum (beduk) in the new campus mosque. The drum is beat in a distinctive pattern before the call to prayer is broadcast.

Because of the successes at UIN Malang, other PTAIN campuses are encouraged to establish a campus pesantren. It remains to be seen if these will be optional and how successful this reproduction will be. It may be that it works in Malang because East Java is where the pesantren community is strongest. Whether or not this model is meaningful or would be successful in other provinces remains

\footnotetext{
${ }^{14}$ (Personal Communication, February 6, 2009)
} 


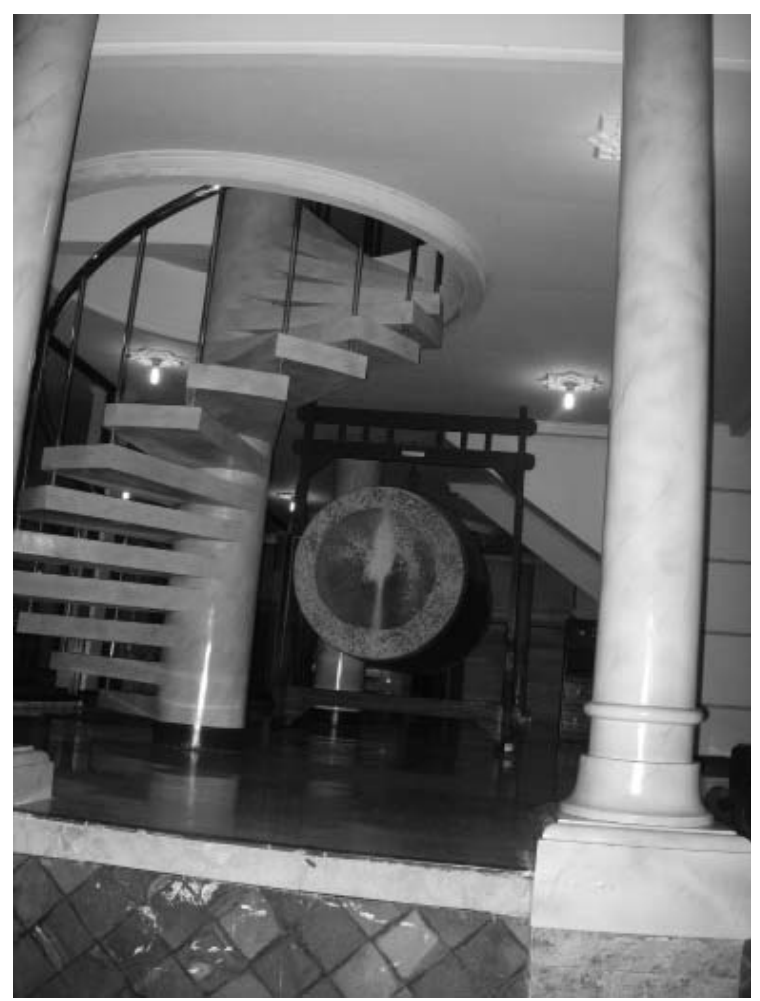

Figure 2: The UIN Malang Campus Mosque Beduk

to be seen. For example, Medan has very few pesantren in the surrounding area (five total) as compared to the thousands found near Malang and Yogya.

In 2009, IAIN Sunan Ampel in Surabaya had a small pesantren which had 160 women and 110 men, most of whom were in one of two scholarship programs from the Ministry of Religious Affairs which targeted special needs in tafsir-Hadith and Islamic family law. Living in the pesantren was a condition of the scholarship. During the day, they took the normal curriculum for IAIN students. The material in the pesantren is not very different from what they study in their regular courses, but it is all in Arabic. The vision for the pesantren is to be a center for language study and for some students to memorize the Quran. At the time, I was told that the women seem to be more serious students and have enough Arabic so that these women were already studying classical texts on mysticism once a week. The men were more attracted to seminars and attended as many as two a week.

UIN Yogya has taken another to strengthen its pesantren roots and to build bridges to local pesantren by taking advantage of a new MORA program for students in Tafsir-Hadiths to receive scholarship contingent on their living in a pesantren. Instead of creating an on-campus pesantren, UIN Yogya has taken advantage of the large number of pesantren in town by negotiating with a number of pesantren to place entire cohorts at a particular pesantren.

As of May 2009, UIN Jakarta had not established a pesantren on campus, but there was considerable concern about creating and maintaining a pesantren environment on the campus. In speaking about the special character of UIN Jakarta, Komaruddin Hidayat emphasized that with the urban nature of the campus it is essential that the atmosphere and values of the madrasah and pesantren are not lost. Hidayat added "not wanting to become a government employee" and "being close to the masses" to the standard list of pesantren values: sincerity (ikhlas),simplicity (kesederhanan), brotherhood, and self-sufficiency(kemandiran). He argued that it is essential that the kind of teacher-student relationship found in pesantren must be continued, so that the professors who come from pesantren can be role models.. This includes deep respect for the teachers on the part of students and deep concern for the students on the part of teachers. To create the communal feeling common to pesantren, he wanted to follow Malang's example. It is the values and character building as well as the place of the kitab kuning and other religious symbols that are most important. Since not all student and teachers come from pesantren, he fears that UIN could lose the pesantren character. For those not from a pesantren, he felt it unwise to force too high a standard upon them but that by creating an Islamic atmosphere, they can be brought along. Hidayat said the community around UIN helps them enforce their values. Most, if not all, landlords enforce single gender roommates and restricted visiting hours for members of the opposite sex. Through a 
landlord association, they encourage landlords to report infractions of the campus morality standards and have even expelled students based on these reports. Further, he argued that in order to keep the pesantren values, the core community needs to come from a pesantren background and their values can be protected as they are modernized. Therefore, he wants to have excellence in the general fakultas so that pesantren graduates want to pursue their degrees there. He argued that it is the pesantren students who are most likely to return to their rural communities with their new knowledge..$^{15}$

\section{QUO VADIS INDONESIA}

I first went to Indonesia in 1987 and fell madly in love. Not with a person, but with the people and the places; I was intoxicated. I decided that I wanted a lifetime of traveling to Indonesia, of studying it, writing and teaching about it. In 1992, I went back for advanced Indonesian language classes. This time, I was in Muslim majority areas of the country; and I still loved it, maybe even more. The Indonesia that I first met was built on an ideal of Unity in Diversity. The reality was never as beautiful as the ideal but it was still amazing. This multi-cultural, multi-religious ideal was not just the product of state mandate; although it was illegal to talk about the sometimes dark reality. Nor was it just a product of the national ideology, Pancasila, which mandated one of five officially recognized religions (it became 6 in 2000); the reality being that traditional, or so called tribal, religions and Chinese religions (other than Buddhism) had no place at the table. At a deep level Indonesians held this ideal dear. The eruption of violence against the Chinese in 1997 and the communal violence of 2000 did not give lie to that ideal. In fact, to the contrary, if this ideal of Unity in Diversity did not have deep roots, these periods of violence could have balkanized the country. Without this ideal, this ideology, the various groups in Indonesia have less in common that the

${ }^{15}$ (interview, February 2009) divisions in the former Yugoslavia. Where did this ideal of unity and pluralism come from?

Those of us with long personal histories with Indonesia ( 25 years, in my case), remember telling friends and family that Indonesians were Muslim but different. The face of Islam in Indonesia still smiles most of the time, but the 1965 involvement of Muslim militias in the slaughter of hundreds of thousands of alleged communists, the 1997 anti-Chinese attacks, the 2000 Christian-Muslim violence in Indonesia, the 2002 and 2005 Bali Bombings, the violence against Ahmaddiyah and even against progressive Muslims like Irshad Manji means that it is not, nor ever was, all smiles and giggles. The tensions that gave rise to these conflagrations have some depth; the ideal of Unity in Diversity was never perfectly realized.

The smiling face of Islam and the ideal of unity was not smoke and mirrors. There is always some disconnect between the ideal and the real in any social system. What is disconcerting is that recently greater numbers of Indonesians are speaking out against that ideal. Without wanting to sound overly dramatic, Indonesia is at a crossroads. Will it continue to be the kind of place where people have religious freedom, not only to choose which religion to practice, but in how to practice it? At least as an ideal? Will it continue to be the kind of place where intellectual figures like the late Nurcholish Madjid and Abdurrahman Wahid, and contemporary figures like Amin Abdullah and Azyumardi Azra shape public opinion to create a rational, tolerant, and multi-religious society? Or will increasingly narrow and intolerant forms of Islam dominate society. The intolerant groups that attack book launchings, commit violence against minority religious groups, and commit acts of terror are a small but significant part of the picture; the bit of kangkung (a spinachlike vegetable) in the smile of Indonesian Islam -- a reminder that the picture is not perfect. There are multiple counter-radical elements in Indonesian Islam that are working to maintain the ideal of Unity in Diversity. Some, but not all, of these efforts are found in State Islamic 
Higher Education system. The vast majority of PTAIN faculty members are committed to a rational and intellectual approach to Islam, and because that approach leads most of them to broader understandings of what it means to be Muslim and to be Indonesian, there is hope for the Indonesia that I first met in 1987 -one which had Unity in Diversity as an ideal, however imperfectly realized -- will continue into the future.

\section{WORKS CITED}

Bruinessen, Martin van. Editor. 2013. Contemporary Developments in Indonesian Islam: Explaining the Conservative Turn. Singapore: ISEAS Publishing.
Jackson, Elisabeth, and Bahrissalim. 2007. "Crafting a New Democracy:Civic education in Indonesian Islamic universities." Asia Pacifc Journal of Education 27(1): 41-54.

Kraince, Richard G. 2000 The Modernization of the National Institute for Islamic Studies

(IAIN) and the Advancement of Muslim Intellectualism in Indonesia. In Islamic Studies in ASEAN. Pattani, Thailand: Prince of Songhla University.

-_-_2008. "Islamic higher education and social cohesion in Indonesia." Prospects 37(3): 345-356.

Steenbrink, Karel. 1974. Pesantren, Madrasah, Sekolah: Pendidikan Islam dalam Kurun Modern. Jakarta: LP3ES. 